\title{
Magnetic resonance evaluation of sacroiliac joint involvement in Behcet's disease: A cross-sectional study
}

\author{
Behçet hastalığında sakroiliak eklem tutulmasının manyetik rezonans ile değerlendirilmesi: Kesitsel \\ bir çalıșma
}

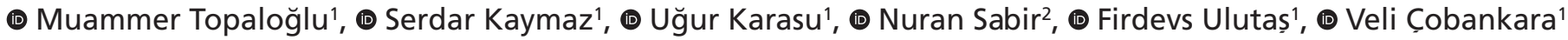 \\ 1 Pamukkale University Faculty of Medicine, Department of Rheumatology, Denizli, Turkey \\ 2 Pamukkale University Faculty of Medicine, Department of Radiology, Denizli, Turkey
}

\begin{abstract}
Objective: To determine the prevalence of sacroiliac joint (SIJ) involvement using magnetic resonance imaging (MRI) in Behcet's disease (BD).

Methods: This cross sectional study evaluated a total of 58 patients diagnosed with BD according to the International Criteria for Behcet's Disease, as well as 50 age- and sex-matched healthy controls. The demographic data of the participants and the clinical and laboratory findings of the BD patients were recorded. All subjects underwent SIJ MRI. Bone marrow edema, synovitis, capsulitis, enthesitis, subchondral sclerosis, erosion, periarticular fat deposition, and ankylosis were evaluated. The images were assessed by two blinded radiologists who specialized in MRI. Interobserver reliability was evaluated using the Fleiss' карра score. The images were recorded as present, absent and suspicious.

Results: The study included 50 patients with BD (25 females, 25 males with a mean age of $39.7 \pm 12.2$ years) and 50 healthy controls ( 25 females, 25 males with a mean age of $39.7 \pm 12.2$ years). Of the BD patients, $4 \%$ also had musculoskeletal involvement. When analyzed using the kappa statistics, the overall kappa score for all MRI findings showed poor agreement. Its value ranges from 0.01 to 0.08 . There was no statistically significant difference between the two groups in terms of the mean values of MRI images ( $p>0.05)$.

Conclusion: The prevalence of SIJ involvement was not different between the BD patients and the healthy controls in our study. SIJ involvement was not a characteristic of BD.
\end{abstract}

Keywords: Behcet's disease, MRI, sacroiliac joint
Öz

Amaç: Behçet hastalığında (BH) manyetik rezonans görüntüleme (MRG) kullanarak sakroiliak eklem (SIE) tutulumunun prevalansını belirlemek.

Yöntem: Bu kesitsel çalıșma için Uluslararası Behçet Hastalığı Kriterlerine göre BH tanısı almıs toplam 58 hasta ve aynı zamanda yas ve cinsiyet açısından eșleștirilmiș 50 sağlıklı kontrol değerlendirilmiștir. Katılımcıların demografik verileri ile BH hastalarının klinik ve laboratuvar bulguları kaydedildi. Tüm deneklere SIE MRG yapıldı. Kemik iliği ödemi, sinovit, kapsülit, entezit, subkondral skleroz, erozyon, periartiküler yağ birikimi ve ankiloz değerlendirildi. Görüntüler, MRG konusunda uzmanlașmıs hastanın durumuna kör iki radyolog tarafından değerlendirildi. Gözlemciler arası güvenilirlik Fleiss'in карра skoru kullanılarak değerlendirildi. Görüntüler mevcut, yok ve șüpheli olarak kaydedildi.

Bulgular: Calıșmaya 50 BH hastası (25 kadın, ortalama yaș 39,7 $\pm 12,2$ yıl olan 25 erkek) ve 50 sağlıklı kontrol (25 kadın, 25 erkek, ortalama yas $39,7 \pm 12,2$ yıl) dahil edildi. BH hastalarının \%4'ünde kas-iskelet sistemi tutulumu da vardı. Kappa istatistikleri kullanılarak analiz edildiğinde, tüm MRG bulguları için genel kappa skoru zayıf uyușuyordu. Değeri 0,01 ile 0,08 arasındaydı. MR görüntülerinin ortalama değerleri açısından iki grup arasında istatistiksel olarak anlamlı fark yoktu ( $p>0,05)$.

Sonuç: Çalıșmamızda SIE tutulum prevalansı BH hastaları ve sağlıklı kontroller arasında farklı değildi. SIE tutulumu BH hastalığının bir özelliği değildi.

Anahtar Kelimeler: Behçet hastalığı, MRG, sakroiliak eklem

\section{Iletișim / Correspondence:}

Serdar Kaymaz MD, Pamukkale University Faculty of Medicine, Deprtment of Rheumatology, Denizli, Turkey

Tel.: +90 5538720626 E-posta: dr.serdarkymaz@gmail.com ORCID ID: orcid.org/0000-0002-6958-5436

Geliș Tarihi / Received: 10.01.2021 Kabul Tarihi / Accepted: 04.03.2021

Atıf / Cite this article as: Topaloğlu M, Kaymaz S, Karasu U, Sabir N, Ulutaș F, Cobankara V. Magnetic resonance evaluation of sacroiliac joint involvement in

Behçet's disease: A cross-sectional study. Ulus Romatol Derg 2021;13(1):12-16

๑Telif Hakkı 2021 Türkiye Romatoloji Derneği / Ulusal Romatoloji Dergisi, Galenos Yayınevi tarafından yayınlanmıștır.

${ }^{\odot}$ Copyright 2021 by the Turkish Society for Rheumatology / Journal of Turkish Society for Rheumatology published by Galenos Publishing House. 


\section{Introduction}

Behcet's disease (BD) is a rare multisystemic disorder typically characterized by chronic and recurrent aphthous ulcers of the mouth and genital region, uveitis, and skin lesions, and may cause inflammation in a range of organs and systems. ${ }^{[1]}$ Musculoskeletal involvement is one of the most common findings among the clinical manifestations of BD. However, there has been an ongoing debate as to whether $\mathrm{BD}$ is one of the seronegative spondyloarthropathies (SpA) or whether sacroiliac joint (SIJ) involvement is a characteristic finding of BD. ${ }^{[2,3]}$ Some authors have reported a high prevalence of SIJ involvement in $\mathrm{BD}$, while others have reported an equal prevalence with healthy controls. ${ }^{[4-7]}$

In the literature, the prevalence of SIJ involvement in $\mathrm{BD}$ has been investigated using pelvic radiograph, computed tomography (CT), and scintigraphy. ${ }^{[3,5,7-}$ 9] Magnetic resonance imaging (MRI) is a radiological diagnostic technique with the highest contrast analysis power for soft tissue. ${ }^{[10]}$ Therefore, it is the most commonly preferred technique to detect SIJ involvement early and to demonstrate active inflammation in joint space, subchondral bone, as well as in adjacent connective tissue. ${ }^{[11]}$ However, there is a limited number of studies investigating SIJ in BD using MRI.

This study aimed to evaluate the prevalence of SIJ involvement in BD patients and healthy controls using MRI.

\section{Materials and Methods}

\section{Patients and Controls}

We conducted a cross-sectional study by enrolling 58 patients diagnosed with $\mathrm{BD}$ and 50 age- and sex-matched healthy controls. ${ }^{[12]}$ The study included patients who were followed up by the rheumatology outpatient clinic of the university and healthy controls who had donated blood to the blood bank of the institution or who were university staff or their family members. All subjects included in the study were informed about the study protocol. Their written informed consent was obtained. The study was conducted in accordance with the principles of the Helsinki Declaration.

\section{Clinical Evaluation}

The healthy controls and BD patients filled out a questionnaire form containing questions about demographic data such as gender and age. The patients' medical treatments and organ involvements were determined. The patients were then assessed by a rheumatologist following a standard protocol, which included a complete history, physical examination, and routine laboratory tests. The clinical diagnosis was confirmed by the International Criteria for Behcet's Disease. Those with a history of a disorder that might cause SIJ involvement [Familial Mediterranean fever (FMF), SpA, sarcoidosis, use of oral isotretinoin, history of tuberculosis and brucellosis, post-partum subjects, osteitis condensans ilii, diffuse idiopathic skeletal hyperostosis, Paget's disease, etc.] were excluded from the study.

\section{Ethics}

The approval for the study was obtained from the local ethics committee (numbered 0.20.05.09). The financial resources required for the study were received from the Scientific Research Project coordination unit of the university (Project no: 2012TPF028).

\section{MRI Evaluation}

The participants underwent SIJ MRI in the department of radiology. MRI examinations were acquired using a 1.5 Tesla Toshiba (Pianissimo, Japan, Tokyo) device. The patients were placed in the supine position with the knees flexed at 15 degrees. The acquired images were evaluated by two radiologists who were blinded to the clinical conditions of the participants.

Bone marrow edema, synovitis, capsulitis, enthesitis, subchondral sclerosis, erosion, periarticular fat deposition, and ankylosis were evaluated on MRI images (Table 1). The images were recorded as present, absent, and suspicious.

\section{Statistical Analysis}

All statistical analyses were carried out using the SPSS Statistics V22.0 for Windows (Statistical Package for the

Table 1. MRI SIJ lesion definitions indicating signs of activity and structural change

\begin{tabular}{|c|c|}
\hline $\begin{array}{l}\text { Bone morrow } \\
\text { edema }\end{array}$ & $\begin{array}{c}\text { It is depicted as a hyperintense signal on STIR images and } \\
\text { usually as a hypointense signal on T1 images. }\end{array}$ \\
\hline Synovitis & $\begin{array}{l}\text { It is diagnosed based on the presence of increased } \\
\text { synovial signal intensity in T2-weighted and STIR } \\
\text { sequences. }\end{array}$ \\
\hline Capsulitis & $\begin{array}{l}\text { It is diagnosed as increased signal on STIR, which is } \\
\text { observed at the perimeter of the joint. }\end{array}$ \\
\hline Enthesitis & $\begin{array}{c}\text { It is diagnosed as increased signal in bone marrow and/or } \\
\text { soft tissue on STIR at sites where ligaments and tendons } \\
\text { attach to bone. }\end{array}$ \\
\hline $\begin{array}{l}\text { Subchondral } \\
\text { sclerosis }\end{array}$ & $\begin{array}{l}\text { It is diagnosed as very low signal on all sequences located } \\
\text { in a typical anatomical area (subchondral bone). }\end{array}$ \\
\hline Erosion & $\begin{array}{l}\text { It is diagnosed as with loss of signal on a T1W non-fat- } \\
\text { suppressed sequence compared with the normal bright } \\
\text { appearance of adjacent bone marrow. }\end{array}$ \\
\hline $\begin{array}{l}\text { Periarticular } \\
\text { fat deposition }\end{array}$ & $\begin{array}{l}\text { It is diagnosed as bright signal seen on a T1W non-fat- } \\
\text { suppressed sequence that is brighter than normal bone } \\
\text { marrow. }\end{array}$ \\
\hline Ankylosis & $\begin{array}{c}\text { It is diagnosed as abnormal bright signal on a T1W non- } \\
\text { fat-suppressed sequence with similar signal intensity to } \\
\text { bone marrow. }\end{array}$ \\
\hline \multicolumn{2}{|c|}{$\begin{array}{l}\text { MRI: Magnetic resonance imaging, STIR: Short tau inversion recovery, T2W: T2 } \\
\text { weighted, T1W: } T 1 \text {-weighted }\end{array}$} \\
\hline
\end{tabular}


Social Sciences Inc., Chicago, IL, USA). Demographic characteristics were expressed using descriptive statistics. The normality of data was tested by the KolmogorovSmirnov test. The statistical analysis of non-normally distributed data was performed using non-parametric tests. The Mann-Whitney $U$ test was used for intergroup comparisons. The chi-square test was used for comparison of qualitative variables. A p-value less than or equal to 0.05 was considered as significant in all statistical tests. Interobserver variability was established with the evaluation of the patients undergoing MRI by two different radiologists at the same clinic appointment (A and B same day). It was evaluated using the Fleiss' каppa score. Kappa scores were interpreted as follows: $<0=$ Poor agreement; $0.01-0.2=$ Slight agreement; 0.21-0.4=Fair agreement; 0.41-0.6=Moderate agreement; 0.61-0.8=Substantial agreement; 0.81-1.0=Excellent agreement.

\section{Results}

A total of 58 patients with $\mathrm{BD}$ were evaluated for eligibility. Of these patients, 8 were excluded from the study, with two due to FMF, two due to a history of tuberculosis, one due to sarcoidosis, two due to the use of isotretinoin, and one due to osteomalacia. So, the study included a total of 50 patients with BD ( 25 females, 25 males with a mean age of $39.7 \pm 12.2)$ and 50 healthy controls ( 25 females, 25 males with a mean age of $39.3 \pm 11.7)$. Of the BD patients, $4 \%$ also had musculoskeletal involvement. All of the BD patients were on non-biologic immunosuppressive therapy. There was no statistical difference between the BD patients and healthy controls in terms of demographic data $(p>0.05)$. The demographic and clinical characteristics of the participants are shown in Table 2.

The radiologists interpreted the MRI findings of the BD patients differently in ten patients (bone marrow edema in one patient, capsulitis in one patient, erosion in two patients, and periarticular fat deposition in six patients). The MRI findings of 8 healthy controls (capsulitis in one healthy control, enthesitis in one healthy control, subchondral sclerosis in two healthy controls and two periarticular deposition in two healthy controls) were interpreted differently. When analyzed using the kappa statistics, the overall kappa score for all MRI findings were poor agreement. Its value ranges from 0.01 to 0.08 . There was no statistically significant difference between the BD and healthy control groups in terms of MRI findings evaluated by two radiologists $(\mathrm{p}>0.05)$ (Table 3$)$.

\section{Discussion}

In the present study, the prevalence of SIJ involvement in $\mathrm{BD}$ was similar to the control group. To our knowledge, this
Table 2. Comparison of demographic, clinical findings and laboratory findings between patients with Behcet's disease and healthy group

\begin{tabular}{|c|c|c|c|}
\hline & $\begin{array}{l}\text { Behcet's } \\
\text { disease } \\
(n=50)\end{array}$ & $\begin{array}{l}\text { Healthy } \\
\text { controls } \\
(n=50)\end{array}$ & p-value \\
\hline \multicolumn{4}{|l|}{ Gender } \\
\hline Male, n (\%) & $25(50 \%)$ & $25(50 \%)$ & $>0.05$ \\
\hline Female, n (\%) & $25(50 \%)$ & $25(50 \%)$ & \\
\hline Age (year) & $39.7 \pm 12.2$ & $39.3 \pm 11.7$ & $>0.05$ \\
\hline \multicolumn{4}{|l|}{ Musculoskeletal involvement } \\
\hline Yes, n (\%) & $2(4 \%)$ & - & - \\
\hline No, n (\%) & $48(96 \%)$ & - & \\
\hline \multicolumn{4}{|l|}{ SIJ involvement } \\
\hline Yes, n (\%) & $4(8 \%)$ & $5(10 \%)$ & $>0.05$ \\
\hline No, n (\%) & $46(92 \%)$ & $45(90 \%)$ & \\
\hline \multicolumn{4}{|l|}{ Laboratory findings } \\
\hline$-C R P(m g / d L), 0-1$, mean \pm std. & $0.78 \pm 0.44$ & - & \\
\hline $\begin{array}{l}\text {-Erythrocyte sedimentation rate } \\
\text { (mm/hour), 0-25, mean } \pm \text { std. }\end{array}$ & $20.80 \pm 14.88$ & - & \\
\hline -WBC, 0-10000, mean \pm std. & $\begin{array}{c}7.6 \pm 2.210^{3 /} \\
\mathrm{mL}\end{array}$ & - & \\
\hline \multicolumn{4}{|l|}{ Medical treatment } \\
\hline Colchicine, n (\%) & $14(28 \%)$ & - & \\
\hline $\begin{array}{l}\text { Colchicine + Immunosuppressant } \\
\text { drugs, n (\%) }\end{array}$ & $22(43 \%)$ & - & \\
\hline $\begin{array}{l}\text { Immunosuppressant drugs + } \\
\text { methylprednisolone, n (\%) }\end{array}$ & $5(10 \%)$ & - & \\
\hline Immunosuppressant drugs, n (\%) & $9(18 \%)$ & - & \\
\hline $\begin{array}{l}\text { CRP: C-reactive protein, The Mann-W } \\
\text { significant, SIJ: Sacroiliac joint, WBC: }\end{array}$ & ney $U$ test was & $\begin{array}{l}\text { ed. }{ }^{*}-p<0.05 \\
\text { d: Standard }\end{array}$ & Statistically \\
\hline
\end{tabular}

Table 3. Magnetic resonance imaging findings of patients included in the study

\begin{tabular}{|c|c|c|c|c|}
\hline & & $\begin{array}{l}\text { Patients } \\
\text { with } \\
\text { Behcet's } \\
\text { disease } \\
(n=50)\end{array}$ & $\begin{array}{l}\text { Healthy } \\
\text { control } \\
(n=50)\end{array}$ & p-value \\
\hline \multirow{2}{*}{$\begin{array}{l}\text { Bone marrow edema } \\
\text { (absent/suspicious/ } \\
\text { present) }\end{array}$} & Radiologist 1 & $46 / 2 / 2$ & $45 / 3 / 2$ & $p>0.05$ \\
\hline & Radiologist 2 & $45 / 3 / 2$ & $45 / 3 / 2$ & $p>0.05$ \\
\hline \multirow{2}{*}{$\begin{array}{l}\text { Synovitis (absent/ } \\
\text { suspicious/present) }\end{array}$} & Radiologist 1 & $50 / 0 / 0$ & $50 / 0 / 0$ & $p>0.05$ \\
\hline & Radiologist 2 & $50 / 0 / 0$ & $50 / 0 / 0$ & $p>0.05$ \\
\hline \multirow{2}{*}{$\begin{array}{l}\text { Capsulitis (absent/ } \\
\text { suspicious/present) }\end{array}$} & Radiologist 1 & $50 / 0 / 0$ & $49 / 1 / 0$ & $p>0.05$ \\
\hline & Radiologist 2 & $50 / 0 / 0$ & $50 / 0 / 0$ & $p>0.05$ \\
\hline \multirow{2}{*}{$\begin{array}{l}\text { Enthesitis (absent/ } \\
\text { suspicious/present) }\end{array}$} & Radiologist 1 & $50 / 0 / 0$ & $50 / 0 / 0$ & $p>0.05$ \\
\hline & Radiologist 2 & $49 / 1 / 0$ & $49 / 1 / 0$ & $p>0.05$ \\
\hline \multirow{2}{*}{$\begin{array}{l}\text { Subchondral sclerosis } \\
\text { (absent/suspicious/ } \\
\text { present) }\end{array}$} & Radiologist 1 & $48 / 2 / 0$ & $49 / 0 / 1$ & $p>0.05$ \\
\hline & Radiologist 2 & $48 / 2 / 0$ & $47 / 2 / 1$ & $p>0.05$ \\
\hline \multirow{2}{*}{$\begin{array}{l}\text { Erosion (absent/ } \\
\text { suspicious/present) }\end{array}$} & Radiologist 1 & $47 / 3 / 0$ & $48 / 2 / 0$ & $p>0.05$ \\
\hline & Radiologist 2 & $49 / 1 / 0$ & $46 / 4 / 0$ & $p>0.05$ \\
\hline \multirow{2}{*}{$\begin{array}{l}\text { Periarticular fat } \\
\text { deposition (absent/ } \\
\text { suspicious/present) }\end{array}$} & Radiologist 1 & $40 / 8 / 2$ & $42 / 8 / 0$ & $p>0.05$ \\
\hline & Radiologist 2 & $43 / 6 / 1$ & $41 / 9 / 0$ & $p>0.05$ \\
\hline \multirow{2}{*}{$\begin{array}{l}\text { Ankylosis (absent/ } \\
\text { suspicious/present) }\end{array}$} & Radiologist 1 & $50 / 0 / 0$ & $50 / 0 / 0$ & $p>0.05$ \\
\hline & Radiologist 2 & $50 / 0 / 0$ & $50 / 0 / 0$ & $p>0.05$ \\
\hline \multirow{2}{*}{$\begin{array}{l}\text { Sacroiliitis (absent/ } \\
\text { suspicious/present) }\end{array}$} & Radiologist 1 & $43 / 5 / 2$ & $42 / 5 / 3$ & $p>0.05$ \\
\hline & Radiologist 2 & $43 / 5 / 2$ & $42 / 5 / 3$ & $p>0.05$ \\
\hline
\end{tabular}


is the first study in the literature investigating the prevalence of SIJ involvement in BD using MRI.

There are contradictory results in the literature regarding the prevalence of SIJ involvement in BD. ${ }^{[2,4,5]}$ Moreover, the fact that the majority of these series have a small sample size makes it more challenging to draw a definitive conclusion. The highest values of SIJ involvement in BD were reported by Dilsen et al. ${ }^{[4]}$, first in 1979 (63\%) and then in 1986 (43\%). In 1983, Caporn et al. ${ }^{[13]}$ reported erosive sacroiliitis in 5 of $14 \mathrm{BD}$ patients in Britain. Olivieri et al. ${ }^{[14]}$ reported an SIJ involvement prevalence of $30 \%$ (four patients) in 20 BD patients.

Another study found SIJ involvement in 35\% of BD patients. ${ }^{[5]}$ Moreover, there are several case reports of the coexistence of SIJ involvement and BD ${ }^{[15,16]}$ However, many researchers have found no relationship between $\mathrm{BD}$ and SIJ involvement. A controlled study by Chamberlain found confirmed SIJ involvement in only one of 34 patients with BD. ${ }^{[2]}$ Benamour et al. ${ }^{[17]}$ recently reported five patients with SpA in a series of 601 patients with BD $(0.83 \%)$, of whom 340 had joint involvement and 4 had bilateral SIJ involvement. In our study, 7\% of the BD patients had SIJ involvement. Therefore, there is a need for large-scale studies to clarify this issue.

Studies in the literature have employed various radiological examinations to determine SIJ involvement. The study by Chang et al. ${ }^{[2]}$ using conventional radiographs found SIJ involvement in $5 \%$ of $\mathrm{BD}$ patients. However, this rate was not different from healthy controls. Yazici et al. ${ }^{[5]}$, on the other hand, found SIJ involvement in $35 \%$ of BD patients. The difference between the results of the aforementioned studies can be attributed to two reasons. The first is the high intraobserver and interobserver variability between those who interpret SIJ radiographs. The second reason may be related to the complex anatomy of the joint and the difficulty of its imaging due to the undulating articular surface. However, another study using CT detected SIJ involvement in $5 \%$ of $\mathrm{BD}$ patients and $7 \%$ of healthy controls. However, the prevalence of SIJ involvement was similar between BD patients and healthy controls (7). Olivieri et al. ${ }^{[14]}$ conducted a similar study using CT scan and reported similar results to the study by Dilsen. The prevalence of SIJ involvement was $30 \%$ in the BD group and 5\% in the control group. Despite being an extremely reliable and valid technique with a high soft-tissue resolution, the number of studies investigating SIJ in BD with MRI is limited. Özelçi et al. ${ }^{[18]}$ evaluated BD patients with SIJ MRI and found SIJ involvement in 20\% of healthy controls and $21 \%$ of BD patients. They emphasized that SIJ involvement was not a characteristic finding of BD disease. In our study, the prevalence of SIJ involvement was similar between healthy controls and BD patients.

\section{Study Limitations}

This study had several limitations, such as not evaluating the effect of disease activity, duration of diagnosis, and predisposing factors for SIJ involvement. Another limitation was that intraobserver variability was not evaluated, and the lesions evaluated to be 'suspicious' were not resolved by radiologists.

\section{Conclusion}

The results of this study demonstrated that SIJ involvement did not appear to be a characteristic finding of BD. Further controlled studies including a larger number of patients are needed to demonstrate whether the severity of disease and genetic factors have an effect on SIJ joint involvement.

\section{Ethic}

Ethics Committee Approval: The approval for the study was obtained from the local ethics committee (numbered 0.20.05.09).

Informed Consent: Their written informed consent was obtained.

Peer-review: Externally and internally peer-reviewed.

\section{Authorship Contributions}

Supervision: S.K., M.T., U.K., N.S., F.U., V.Ç., Concept: S.K., M.T., U.K., N.S., F.U., V.Ç., Design: S.K., M.T., U.K., N.S., F.U., V.Ç., Data Collection or Processing: S.K., M.T., U.K., N.S., F.U., V.Ç., Analysis or Interpretation: S.K., M.T., U.K., N.S., F.U., V.Ç., Literature Search: S.K., M.T., U.K., N.S., F.U., V.Ç., Writing: S.K., M.T., U.K., N.S., F.U., V.Ç.

Conflict of Interests: No conflict of interests was declared by the authors.

Financial Disclosure: The financial resources required for the study were received from the Scientific Research Project coordination unit of the university (Project no: 2012TPF028).

\section{References}

1. Biçer A. Musculoskeletal findings in Behcet's disease. Pathol Res Int 2012:1-5.

2. Chang HK, Lee DH, Jung SM, et al. The comparison between Behçet's disease and spondyloarthritides: does Behçet's disease belong to the spondyloarthropathy complex? J Korean Med Sci 2002;17:524-9.

3. Chamberlain MA, Robertson RJ. A controlled study of sacroiliitis in Behçet's disease. Br J Rheumatol 1993;32:693-8.

4. Dilsen N, Konice M, Ovul C. Arthritic patterns in Behçet's disease. In: Dilsen N, Konice M, Ovul C, editors. Behçet's disease. Amsterdam, Oxford: Excerpta Medica; 1979:145-55. 
5. Yazici H, Tuzlaci M, Yurdakul S. A controlled survey of sacroiliitis in Behçet's disease. Ann Rheum Dis 1981;40:558-9.

6. Olivieri I, Salvarani C, Cantini F. Is Behçet's disease part of the spondyloarthritis complex? J Rheumatol 1997;24:1870-2.

7. Kotevoglu N, Tasbas I, Bekiroglu N. Computed tomography does not support sacroiliitis as a feature of Behçet disease: a metaanalytic review. J Clin Rheumatol 2004;10:42-5.

8. Maghraoui AE, Tabache F, Bezza A, et al. A controlled study of sacroiliitis in Behçet's disease. Clin Rheumatol 2001;20:189-91.

9. Sahin M, Yildiz M, Tunc SE, et al. The usefulness of Tc-99mMDP bone scintigraphy in detection of articular involvement of Behçet's disease. Ann Nucl Med 2006;20:649-53.

10. Erdem OL, Erdem ZC, Sarıkaya S. Sacroiliitis in patients with ankylosing spondylitis: the findings of magnetic resonance imaging. Rheumatology 2004;19:153-8.

11. Guglielmi G, Scalzo G, Cascavilla A, Carotti M, Salaffi F, Grassi $W$. Imaging of the sacroiliac joint involvement in seronegative spondylarthropathies. Clin Rheumatol 2009;28:1007-19.

12. International Team for the Revision of the International Criteria for Behçet's Disease (ITR-ICBD). The International Criteria for Behçet's Disease (ICBD): a collaborative study of 27 countries on the sensitivity and specificity of the new criteria. J Eur Acad Dermatol Venereol 2014;28:338-47.

13. Caporn N, Higgs ER, Dieppe PA, Watt I. Arthritis in Behcet's syndrome. Br J Radiol 1983;56:87-91.

14. Olivieri I, Gemignani G, Camerini E, Semeria R, Pasero G. Computed tomography of the sacroiliac joints in four patients with Behcet's syndrome. Br J Rheumatol 1990;29:264-7.

15. Tosun M, Uslu T, Ibrahim IH, Bahadir S, Erdolu S, Guler M. Coexisting ankylosing spondylitis and Behcet's disease. Clin Rheumatol 1996;15:615-20.

16. Kallel MH, BejiaI, Fournie B, Fournie A. Behcet syndrome with ankylosing spondylitis. Rev Rhum 1995;62:295-9.

17. Benamour S, Zeroual B, Alaoui FZ. Joint manifestations in Behcet's disease. A review of 340 cases. Rev Rhum 1998;65:299-307.

18. Özelçi R, Şahin Ö, Öztoprak İ, Hayta E, Kaptanoğlu E, Elden H. Behçet hastalığında manyetik rezonans görüntüleme ile sakroiliit sıklığının belirlenmesi. Cumhuriyet Tıp Derg 2010;32:298-302. 